\title{
O coro trágico de Pasolini
}

\author{
PASOLINI'S TRAGIC CHORUS \\ Bruno C. Duarte
}

Universidade Nova de Lisboa

Lisboa, Portugal

\section{Resumo}

Na segunda metade da década de 60, entre obras como Édipo Rei (1967) e Medeia (1969), Pasolini projetou realizar um filme-poema "sobre o Terceiro Mundo". Dessa "espécie de documentário, um ensaio", nas suas próprias palavras, foram preservados vários fragmentos em película. Entre eles estão as Notas para uma Oresteia africana (1968-69), uma tentativa de transposição da obra de Ésquilo na África moderna pós-colonial - e de chegar assim à projeção e deslocação da forma e do mito trágicos num espaço e num tempo extrâneos que lhe resistem por inerência. No contexto deste projeto, a ambiçáo de Pasolini de ressuscitar e ressituar o coro grego antigo "nas suas situaçôes reais, realísticas, quotidianas" da África do século XX mostra ser especialmente relevante não apenas para reavaliar a figura - essencialmente paradoxal - de um coro trágico moderno, mas também para reconsiderar a construção do espaço dramático, assim como o conceito de representação em geral.

\section{Abstract}

During the second half of the 1960s, among such works as King Oedipus (1967) and Medea (1969), Pasolini planned to direct a filmpoem "about the Third World". From this "sort of documentary, an essay", in his own words, several fragments have remained on film. Among them are the Notes towards an African Oresteia (196869), an effort to transpose Aeschylus' work onto post-colonial modern Africa - and therefore to arrive at the projection and displacement of tragic form and myth onto an extraneous space and time that intrinsically tend to resist it. In the context of this project, Pasolini's ambition to revive and relocate

\section{Résumé}

Pendant la deuxième moitié des années 60, parmi des oeuvres comme Oedipe-Roi (1967) et Médée (1969), Pasolini eut le projet de réaliser un film-poème "sur le tiers-monde". De cette "espèce de documentaire, un essai", dans ses propres mots, plusieurs fragments ont été préservés, parmi lesquels les Notes pour une Orestie africaine (1968-69), une tentative de transposition de l'oeuvre d'Eschyle dans l'Afrique moderne post-coloniale - et d'arriver ainsi à la projection et au déplacement de la forme et du mythe tragiques dans un espace et un temps étrangers qui lui résistent intrinsèquement. Dans ce contexte, l'ambition de Pasolini de
Palavras-chave: Antigo/Moderno, Coro trágico, Tragédia grega, Oresteia, Cinema.

Keywords: Ancient/Modern, Tragic Chorus, Greek Tragedy, Oresteia, Cinema.

Mots-clés: Ancien/Moderne, Choeur tragique, Tragédie grecque, Orestie, Cinéma. 
the ancient Greek chorus in several "real, realistic, daily situations" of $20^{\text {th }}$ century Africa remains especially relevant not only to reassess the essentially paradoxical figure of a modern tragic chorus, but also to reconsider the construction of dramatic space as well as the concept of representation in general. faire revivre et de re-situer le choeur grec ancien dans les "situations réelles, réalistes, quotidiennes” de l'Afrique du XXème siècle s'avère être particulièrement importante non seulement pour considérer encore la figure - essentiellement paradoxale - d'un choeur tragique moderne, mais aussi pour repenser la construction de l'espace dramatique ainsi que le concept de représentation en général.
* (PASOLINI, Pier Paolo. Saggi sulla politica e sulla società. Ed. W. Siti, S. de Laude. Tutte le opere. Milão: Mondadori, 1999: 199.)

\section{Uma 'Oresteia Africana'}

Na segunda metade da década de 60, sensivelmente no mesmo período em que realizou Édipo Rei (1967) e Medeia (1969), Pier Paolo Pasolini manteve durante algum tempo o projeto de realizar um outro filme, provisoriamente intitulado Notas para um poema sobre o Terceiro Mundo, que seria organizado em vários episódios e situado sucessivamente em regiōes como a África, a Índia, os países árabes, a América Latina, ou os ghettos da América do Norte. Dessa "espécie de documentário, um ensaio", * nas palavras do próprio Pasolini, restaram vários rascunhos e esboços, como, por exemplo, o curta-metragem Appunti per un film sull'India (1967-68), os Sopraluoghi in Palestina, captados durante as filmagens para $O$ evangelho segundo S. Mateus (1964), ou o documentário Le mura di Sana'a (1970), realizado no Iêmen. Desse vasto projeto faziam parte também os Appunti per un'Orestiade africana (1968-69), que tiveram como ponto de partida uma viagem que Pasolini fez pela Tanzânia e por Uganda, entre o final de 1968 e o início de 1969, e que, como se torna claro através do título, consistem formalmente numa série de estudos preliminares para transpor uma das obras maiores de Ésquilo, a Oresteia, na África moderna pós-colonial. ${ }^{1}$

Segundo Pasolini, as Notas para uma Oresteia africana não devem ser vistas como "um verdadeiro filme, no sentido próprio",

\footnotetext{
${ }^{1}$ Em 1960, Pasolini concluiu uma tradução da Oresteia, a pedido de Vittorio Gassmann, que resultou numa encenação do texto apresentada publicamente nesse mesmo ano. A sua "Carta do tradutor" (1960) constitui por assim dizer a sua declaração de princípios a respeito da matéria e da essência da tragédia de Ésquilo. Cf. Gallo, I. "Pasolini traduttore di Eschilo". In: Todini, U. (org.). Pasolini e l'antico. I doni della ragione. Nápoles: ESI, 1995: 33-43.
} 
mas antes como "um filme por fazer", * ou seja, como um conjunto de apontamentos e planos, um filme sobre um filme que tem ainda de surgir. Este ponto é determinante, pois dirige a atenção para as propriedades formais da obra enquanto tal - mesmo tratando-se de um fragmento, ou, acima de tudo, porque se trata de um fragmento.

A estrutura do filme é baseada no comentário falado do próprio Pasolini, à medida que atravessa com a sua câmara vários territórios e cidades da África central, procurando locais de filmagem e personagens potenciais, figuras abstratas ou individuais que poderiam entrar no seu filme - por vezes escolhendo o método de improvisação, ou tentando reconstituir e dar vida a algumas das cenas da tragédia com os habitantes locais. Esta sequência de imagens aparece em alternância com imagens de arquivo dos conflitos no Biafra, que ocorreram naqueles anos, como alusão metafórica à Guerra de Tróia; e inclui segmentos em que se vê o realizador discutindo o seu filme com um grupo de estudantes africanos na Universidade de Roma.

Pasolini encarou o seu filme não como um documentário no sentido estrito, nem como uma narrativa convencional, entendida como a tentativa de restituir com a devida fidelidade - filológica ou cénica - a tragédia grega. Em vez disso, ele descreveu o gênero dos "appunti" - as "notas" ou anotaçóes para um filme futuro - como pertencendo a um "estilo sem estilo", * algo que possui uma linguagem própria e responde apenas às suas leis. Também designou mesmo o estilo desse filme em particular como sendo "composto e espúrio",* o que explica em larga medida a sua dupla natureza: por um lado, extremamente rígido nas suas suposiçôes e premissas, que remetem para uma imagem metafórica e redentora da África; por outro, fortemente enraizado na indeterminação e experimentação. Sendo um filme que prepara e antecipa um filme por vir, é necessariamente também um filme que reflete sobre si mesmo, e que por isso vacila constantemente no limite da sua possibilidade como processo. Ao mesmo tempo, a sua incompletude não é tão involuntária quanto poderia parecer à primeira vista - há nela algo de premeditado, e mesmo de obstinado, como se verá.

São inúmeras as implicaçôes desse filme: algumas claramente políticas, outras de natureza antropológica ou etnográfica, outras ainda religiosas. Há, contudo, um ponto único, por via de um exemplo, no qual todas se concentram: o que Pasolini tem a dizer sobre o coro grego antigo renascido na África moderna. As suas pala-
* (PASOLINI, Pier Paolo. Entrevista com Lino Peroni (1968). In:____. Per il Cinema II, Ed. W. Siti, F. Zabagli, Milão: Mondadori, 2001: 2935-2936.)

* (PASOLINI, Pier Paolo. Appunti per un'Orestiade africana. In:_. Per il Cinema I, Ed. W. Siti, F. Zabagli, Milão: Mondadori, 2001: 1185.)

* (PASOLINI, Pier Paolo. Per il Cinema l, op. cit.: 2681.) 
vras a esse respeito se tornam especialmente relevantes não apenas por pensarem de novo a figura - essencialmente paradoxal - de um coro trágico moderno, mas porque reconsideram e medem de novo, desde o seu início, o conceito de representação em geral. ${ }^{2} \mathrm{O}$ coro surge como uma estrutura, uma armação - no sentido mais preciso do termo - na qual se trata de cingir e de traçar uma construção específica do espaço dramático, na medida exata em que é posto em movimento o sentido político profundo da tragédia grega.

\section{As Erínias na África}

A ambição de Pasolini é a de transpor a Oresteia - a única trilogia preservada da Grécia Antiga, apresentada pela primeira vez em Atenas em 458 a.C. - na África do século XX, isto é, ressituar ou deslocar o mito grego do seu tempo natural ou original para a história moderna. A isso chama ele, literalmente, uma "ambientação" da Oresteia na África.

A Oresteia conta o ciclo de assassínio e vingança que se abate sobre a casa de Atreu ao longo de várias geraçôes. As suas três partes desenham uma longa cadeia de morte e expiação: Orestes assassina a sua mãe, Clitemnestra, para vingar a morte de seu pai, Agamémnon, Rei de Argos, que por sua vez tinha sacrificado a sua filha, Ifigénia. Depois da morte de sua mãe, a mente de Orestes começa a estremecer: é perseguido e atormentado pelas Erínias, também chamadas de Fúrias, deusas primitivas do mundo subterrâneo que vêm punir aqueles que são culpados de crimes de sangue no seio da família, e exigir o seu sacrifício. Na terceira e última parte da trilogia, intitulada "Eumênides”, Orestes, protegido por Apolo, é forçado a enfrentar o Areópago, o Tribunal ateniense, e é depois absolvido e perdoado pela deusa Atena, que preside ao Tribunal.

\footnotetext{
${ }^{2}$ A maior parte dos estudos dedicados às "Notas para uma Oresteia africana” não se demoram sobre a figura do coro: limitam-se a reproduzir os comentários de $\mathrm{Pa}$ solini sobre a sua instrumentalização poético-política. Algumas excepções: MEDDA, E. "Rappresentare l'arcaico. Pasolini ed Eschilo negli Appunti per un'Orestiade africana”. In: FABBRO, E. (org.). Il mito greco nell'opera di Pasolini. Udine: Forum, 2004: 117, 123-126. CALABRETTO, R. "La musica nella 'trilogia classica’ di Pier Paolo Pasolini”. In: FABBRO, E. op. cit.: 149-151. FUSILLO, M. "Pasolini's Agamemnon. Translation, Screen Version and Performance." In: MACINTOSH, F.; MICHELAKIS, P.; HALL, E.; TAPLIN, O. (Org.). Agamemnon in Performance 458 BC to AD 2004. New York: Oxford University Press, 2005: 229-230. FUSILLO, Massimo. La Grecia secondo Pasolini. Mito e cinema. Florença: NIES, 1996: 190-214, 234-242.
} 
As Erínias, relutantes em aceitar este juízo, continuam a exigir o castigo de Orestes, mas Atena consegue apaziguá-las, até que, por fim, elas são transformadas nas Eumênides, não já criaturas irracionais, vorazes e sanguinárias, mas divindades benevolentes que passam a agir como guardiâs da justiça.

No seu filme, Pasolini, que começa por resumir o enredo da Oresteia, sublinha imediatamente a importância desta última parte da trilogia. As suas motivaçóes, se acreditarmos no seu testemunho, são estritamente políticas - e o mesmo poderia ser dito da sua leitura de toda a tragédia de Ésquilo. Numa palavra, ele descobre uma analogia entre a substância central do drama grego e a condição da maioria dos estados africanos, no momento da sua libertação do colonialismo. A sua convicção é a de que a Oresteia prefigura a questão iminente da África moderna, que - no final dos anos 60 - se encontra numa encruzilhada, dividida entre o seu passado e o seu futuro, isto é, envolta num momento de transição entre uma cultura tribal e pré-histórica, e o começo do racionalismo e da democracia formal trazidos pelo mundo ocidental. Mais que isso, ele está convencido de que essa transição de um para outro plano se encontra consubstanciada na cena que se descreve no final da trilogia de Ésquilo: o momento em que as obscuras Erínias (as deusas aterradoras da noite e da vingança) são subjugadas e transformadas nas doces e clementes Eumênides, que significam a fusão da ira incontrolável com a serenidade da contenção e da sobriedade. O seu sonho - ou melhor: a raiz da sua ideologia - é o de que, nessa passagem, a civilização arcaica ou primitiva será preservada e integrada na nova ordem racional da sociedade tornada possível pelos valores ocidentais, e simbolizada aqui por Atena. Ela é a "deusa branca" que "ensinou a Orestes a democracia, instituindo o primeiro tribunal humano", tal como as Eumênides são as "deusas da irracionalidade num mundo racional": o mundo tribal e irracional antigo sobrevive no novo mundo da razáo, que é apenas o seu "complemento necessário".* Teria, assim, lugar uma autêntica incorporação, uma inclusão silenciosa, na qual as forças primevas do mito e da sacralidade continuariam a resistir e a subsistir no interior da autonomia do progresso. Para Pasolini,

(...) a Oresteia sintetiza a história da África destes últimos cem anos, isto é, a passagem quase brusca e divina de um estado "selvagem" para um estado civil e democrático: a sucessão dos Reis que, na dura estagnação secular de uma cultura tribal e pré-histórica, dominaram

* (PASOLINI, Pier Paolo. "L'Atena bianca". In: Per il cinema I, op. cit.: 1202 1203.) 
* (PASOLINI, Pier Paolo. "Nota per l'ambientazione dell'Orestiade in Africa" (1968-69). In: Per il cinema I, op. cit.: 1999-1200.)

* (Ibidem: 1200.)
- por seu lado sob o domínio das negras Erínias - as terras africanas de algum modo despedaçou-se subitamente: a Razão instituiu quase motu proprio instituiçôes democráticas. É preciso acrescentar que o problema realmente urgente e atual, agora, nos anos sessenta - os anos do Terceiro Mundo e da "negritude" - é a "transformação das Erínias em Eumênides”: e, neste ponto, o génio de Ésquilo antecipou tudo. Todas as pessoas evoluídas estão de acordo [...] quanto ao fato de que a civilização arcaica - a que, de modo superficial, se chama folclórica - não deve ser esquecida, desprezada e traída. Deve, em vez disso, ser assumida no interior da nova civilização, integrando esta última, e tornando-a específica, concreta, histórica. As divindades terríveis e fantásticas da Pré-história africana devem passar pelo mesmo processo das Erínias, e tornar-se Eumênides.*

\section{"Cantai e dançai..."}

São essas - de acordo com Pasolini - as "razóes estruturais de uma transposição da Oresteia no mundo africano." Como ele diz também, no entanto, são essas as razões, “[...] mas, como sempre, quando tais razóes são justas, abrem perspectivas de encenação dramática e artística inesperadas e seguras".* Ou seja: muito embora sejam claras as suas ideias quanto aos motivos que o levam a querer transpor a Oresteia na paisagem africana, e apesar de náo ter qualquer dúvida sobre a relevância lógica da analogia que procura, resta-lhe agora decidir como executar essa analogia. Depois de ter substanciado e justificado as bases e os fundamentos para o seu projeto, ele é confrontado com o problema específico de encontrar uma maneira, um modo de o apresentar. Nesse ponto, não deixa de ser marcante e decisivo que ele escolha, como exemplo para esse repto e para essa dificuldade - o coro. Pasolini:

Basta pensar por exemplo na magnífica função que podem ter os coros num filme africano: basta pegar em pessoas de uma aldeia qualquer [...] e dizer a essa gente: "Cantai e dançai", e eis que os coros gregos parecerão renascer: bastará introduzir como didascália, abaixo daquelas vozes selvagens que cantam, as palavras clarificantes e evocadoras do coro. [...] Basta pensar no sentido de realidade que podem transmitir as Erínias, cobertas por vestes e horríficas tatuagens africanas: sentido de realidade que nenhum disfarce e nenhum traje cénico poderiam alcançar, num filme ambientado na Europa. Basta pensar numa figura como a de Cassandra, que prevê, ou melhor, vê fisicamente a própria morte [...] e a descreve: também este "solo" de Cassandra poderia ser todo ele cantado, naquela espécie de transe que se apodera muitas vezes dos negros quando cantam.* 
Sem qualquer embaraço, Pasolini imagina assim um "musical trágico", todo ele erigido a partir da "tragicidade mística que é típica do canto negro".* Num sentido geral, toda essa observação poderia ser vista como típica da sua visão da África, que se mantém essencialmente intuitiva, e muitas vezes não está isenta de um tom sentimental, paternalista e nostálgico - ecoando a celebração de um primitivismo e de uma inocência perdidos ou deixados intactos em si mesmos. A África, como ele admitiu ou insinuou frequentemente nos seus textos, tornara-se a sua "única alternativa"* - o terreno que era preciso salvar ou resgatar, e também a resposta para os males do mundo, tal como ele o conhecia, corrompido pelo neocapitalismo e pelo seu correlato mais próximo, mais ameaçador, o consumismo, a tecnocracia e a desumanização do mundo. A luz redentora do "Outro" - o Terceiro Mundo como protoconceito da alteridade e efusão última do anseio revolucionário - proporcionou-lhe a contraimagem da Europa em declínio. A sua representação da "África nova, a África do futuro" como "síntese da África moderna independente, livre, e da África antiga", era declaradamente política: nela jogava-se toda a ideia e todo o destino do comunismo, e, assim também, da "solução marxista", ${ }^{*}$ isto é, o seu valor de denúncia e o seu sentido efetivo, mas igualmente a perspectiva sombria do seu estertor ou do seu adiamento sucessivo. No meio da reverência e da admiração próprias à voracidade do seu encantamento, e apesar de todos os seus esforços no sentido de conhecer de perto o seu objeto e fazer justiça à sua complexidade real, à sua "realidade", ele não podia aqui evitar cair no estado sonhador, desejante de uma (pré-)história que se desenhava apenas ao fundo, com contornos líricos e difusos, na similitude do mito e da realidade.

Uma grande parte desse pathos de devoção era eminentemente contemplativo, e não excluía a sua rendição - por vezes relutante, mas sempre consciente - ao signo do exótico e do pitoresco. Em causa estava o encontro de Pasolini com o "espírito africano", o olhar fixo pousado sobre o movimento dos corpos como estátuas vivas no espaço, e sobre os seus atributos naturais, da vivacidade à graça e à "doçura animal", da violência à leveza, do erotismo à pureza. Esse olhar reaparece muito claramente na passagem citada acima: Pasolini identifica candidamente nas danças rituais das tribos africanas a personificação imediata do coro grego. O recesso "selvagem" ou "frenético" da dança, a intuição da sua potência rítmica
* (Ibidem.)

* (PASOlINI, Pier Paolo. "Frammento alla morte". In:_______ Tutte le poesie I. Ed. Walter Siti. Milão: Mondadori, 2003: 1050.)

* (PASOLINI, Pier Paolo. Per il cinema I, op. cit.: 1194.)

* (PASOLINI, Pier Paolo. Saggi sulla politica e sulla società, op. cit.: 1576.)

* (PASOLINI, Pier Paolo. Per il cinema l, op. cit.: 1196.) 
e dramática significa para ele o princípio espontâneo de demonstração do paralelismo que torna equidistantes o teatro antigo e o mundo arcaico africano (pré-)moderno.

Para chegar a perceber de que maneira uma afirmação como esta pode ser sustentada em toda a sua força, e intuir ao mesmo tempo as razóes da sua vulnerabilidade, ou da sua ingenuidade, seria preciso considerar por alguns momentos o problema genérico que ela coloca de antemão.

\section{O coro real}

É sabido que qualquer tentativa de transpor a estrutura dramática da tragédia grega no teatro moderno se vê confrontada com dificuldades quase insuperáveis; e o mesmo se aplica ao cinema, com a agravante ainda de outros constrangimentos e consequências. As razōes para isso parecem decorrer em grande parte do desconhecimento das leis internas e da prática teatral do drama trágico na Grécia antiga, ou dos meios de que dispomos para a reconstruir, ou melhor, para a questionar - à luz da nossa ambição quanto ao que podem ou devem ser a arte dramática e a representação teatral. Parece existir - abreviando um tema muito complexo ${ }^{3}$ - uma percepçáo divergente do tempo e do espaço, no que diz respeito quer à essência, quer à execução do drama trágico, uma discórdia ou desarmonia de princípio que, por ser impossível de erradicar, suscita, em alternância, a atraçáo e a resistência de uma estrutura a outra.

Um exemplo flagrante desse fenômeno é, evidentemente, a necessidade de descobrir ou decidir o que fazer com o coro. Apesar dos muitos avanços realizados até aqui no domínio dos estudos clássicos, que permitiram seguramente alcançar uma compreensão mais profunda de muitas dessas questóes, ${ }^{4}$ o coro enquanto tal mantém-se esquivo quanto ao grau de autenticidade ou verossimilhança da sua entrada em cena, numa palavra, da sua silhueta

${ }^{3}$ Da extensa bibliografia sobre essa questão, quatro exemplos maiores: TAPLIN, O. Greek Tragedy in Action, Londres, 1978. FLASHAR, H. Inszenierung der Antike. Das griechische Drama auf der Bühne der Neuzeit 1580-1990, Munique, 1991. GOLDHILL, S.; OSBORNE, R. (ed.). Performance Culture and Athenian Democracy, Cambridge, 1999. WALTON, J. M. The Greek Sense of Theatre. Tragedy reviewed, Londres/New York, 1984.

${ }^{4}$ Cf. RIEMER, P.; ZIMMERMAN, B. Der Chor im antiken und modernen Drama. Beiträge zum antiken Drama und seine Rezeption, Estugarda, Weimar, 1999. WEBSTER, T. B. L. The Greek Chorus, Londres, 1970. GRUBER, M. A. Der Chor in den Tragödien des Aischylos. Affekt und Reaktion, Tübingen, 2009. 
e do seu movimento. É essa, muito provavelmente, a natureza do seu fascínio, a de que os dois elementos essenciais que dão forma ao coro grego antigo, o canto e a dança na sua simultaneidade, permanecerão para sempre algo de irrecuperável, que nos é impossível apreender inteiramente, e, por isso mesmo, algo a que podemos apenas aspirar - na nossa própria experiência da poesia dramática. Na prática, "o coro é o pesadelo de qualquer encenador. Quase nunca 'resulta'. Vezes sem conta, a sua presença espectral prova a alteridade impossível dos Gregos".*

Nas suas Notas para a Oresteia, Pasolini insiste repetidamente nesta questáo de saber de que modo pretende chegar à representação do coro. Não muito longe do início do filme, de forma muito deliberada, ele afirma desejar que o seu "filme sobre a Oresteia na África seja um filme cujo caráter seria essencialmente popular", e que, nesse sentido, está empenhado em "atribuir uma enorme importância ao coro, o coro que nas tragédias gregas fala em uníssono, imóvel no palco", enquanto que, agora, "gostaria naturalmente de o distribuir nas suas situaçôes reais, realísticas, quotidianas".*

Paralelamente à busca de um local e dos principais protagonistas da trilogia, ele dá início à "procura dos personagens do coro", ${ }^{*}$ e prossegue recitando ele mesmo partes da Oresteia - como o hino a Zeus, uma parte central do parodos da primeira tragédia, Agamêmnon - enquanto assistimos a imagens e fragmentos da vida de todos os dias na África: mães com os seus filhos, uma mulher que retira água de um poço, camponeses que vão ao mercado, trabalhadores, pessoas que conversam na rua ou no seu local de trabalho, fábricas, escolas, e assim por diante. A sua convicção é a de que existe nessa simples existência quotidiana do povo um elemento de realismo, de verdade, no qual está contido um "momento mítico e sacral"* - consanguíneo ao texto de Ésquilo. Em suma, o coro trágico, revestido do seu carácter popular, surge aqui acima de tudo como a instância que introduz - figurativamente falando e falando figurativamente - a semelhança, a simetria que liga entre si, sob a égide da "descoberta da democracia" cumprida por Orestes, a "cultura arcaica grega" e a "cultura tribal africana”.*

\section{"Agora vais ouvir o hino que te há-de acorrentar"}

O axioma de Pasolini segundo a qual a obra de Ésquilo - e assim, de algum modo, toda a tragédia grega - pode ser vista como
* (GOLDER, Herbert; SCULLY, Stephen. (org.): "The Chorus in Greek Tragedy and Culture". In: LEY, Graham. The Theatricality of Greek Tragedy. Playing Space and Chorus. Chicago/Londres, UCP, 2007: 114.)

* (PASOLINI, Pier Paolo. Per il cinema l, op. cit.: 11781179.)

* (Ibidem: 1179.)

*(Ibidem: 1180.)

* (Ibidem: 1181.) 
* (PASOLINI, Pier Paolo. Per il cinema, op. cit.: 1177-78.) uma prefiguração da história africana pós-colonial do século XX, está longe de ser uma simples proposição teórica. Na verdade, a determinação que o impele para diante não é tanto a urgência de demonstrar, mas muito mais o impulso de materializar a sua analogia.

A sua grande luta está em abdicar da narratividade como meio de apresentar a tragédia grega no cinema. Precisamente por isso, o seu instinto leva-o a querer traduzir o texto original em música: em vez de ter alguém que recita, o seu desejo é encontrar alguém que possa cantar a Oresteia. Uma das cenas principais de Agamêmnono confronto de Cassandra com o coro, depois da sua profecia sobre a morte de Agamêmnon - é transformada, num dado momento do filme, numa improvisação "no estilo do jazz", que inclui dois cantores-atores afro-americanos, interpretada sob o signo híbrido da dissonância e do êxtase. ${ }^{5}$ Este excurso aparente, que se junta aos cantos populares africanos e à música dita tribal que compóem a banda sonora do filme, não pretende ser nem ilustrativo nem reprodutivo em relação ao texto grego, mas um regresso à forma originária do canto, uma espécie de música absoluta no seu estado primitivo, crua e pura em simultâneo. Nessa vertigem de um lirismo não-verbal e possuído que se quer subtrair ao tempo e à história e se procura si mesmo no limiar do mítico, é já ostensivo o plano da simulação e da idealidade. ${ }^{6}$

Um outro exemplo concede maior clareza à natureza da analogia como presságio: o momento em que Pasolini se questiona sobre como representará as Erínias. Assombrado e perseguido pelo assassinato da sua mãe Clitemnestra, Orestes não tem descanso: as "deusas do terror atávico, ancestral", * assaltam a sua mente com a sua presença, as suas danças e os seus cantos, os seus murmúrios, os seus gritos opressivos. Logo na primeira parte da trilogia, Cassandra invoca o coro das Erínias, que cantam a canção da morte, devida a Orestes, manchado da culpa pelo mais grave de todos os atos de transgressão:

\footnotetext{
${ }^{5}$ A música original é do saxofonista Gato Barbieri, acompanhado por Yvonne Murray, Archie Savage, D.F. Moye, M. Mellio. Cf. CALABRETTO, Roberto. Pasolini e la musica. Pordenone: Cinemazero, 1999: 434, 484-485.

${ }^{6}$ MACKINNON, Kenneth. Greek Tragedy into Film. Rutherford/Madison/Teaneck: AUP, 1986:154-156, registra a decisão de Pasolini de "tornar o drama operático, em vez de falado", mas se refere em termos quase sarcásticos à "performance jazz-operática” incluída no filme.
} 
[...] Sede testemunhas de que eu há muito sigo, farejando, a pista de crimes outrora cometidos. É que desta casa jamais se afasta um coro que canta em uníssono, mas sem melodia, pois desagradáveis são as suas palavras. É um grupo de alegres foliōes que, para ousar mais, ingeriu sangue humano e se mantém em casa, difícil de desalojar, o grupo das Erínias criadas nesta raça. Unidas ao palácio, elas fazem ressoar o seu canto, canto da cegueira do espírito que começou tudo e, uma após outra, exprimem a sua aversão ao crime cometido contra o leito fraternal, a sua hostilidade àquele que o calcou.*

Nas "Eumênides", no momento em que Orestes chega a Atenas e abraça a estátua de Atena, na esperança de receber o seu perdão, o coro das Erínias - que seguiam no seu rasto e acabam de entrever a sua figura - aparece subitamente para o confrontar:

Não, nem Apolo nem a força de Atena te poderão salvar. Abandonado de todos, vais ao encontro da ruína, depois de perderes todo o sentido da alegria, pasto sem sangue das deusas, sombra.

Tu não respondes e cospes as minhas palavras, tu, vítima engordada para o meu sacrifício! E será vivo, sem imolação no altar, que me servirás de festim. Agora vais ouvir o hino que te há-de acorrentar.

O primeiro estásimo, que começa imediatamente a seguir, sublinha a qualidade reflexiva da intervenção do coro, insistindo na fusão do canto com o movimento:

Vamos, dancemos em roda, pois queremos erguer um canto de horror, dizendo como o nosso bando atribui aos mortais a sua sorte.*

Alguns versos mais adiante, no primeiro refrão, esta palavra intensifica-se:

Mas sobre a nossa vítima se ergue este canto que é loucura, que é delírio onde se anula a razão, o hino das Erínias, que acorrenta as almas, hino sem lira, que mirra os mortais.*

É este, pois, o dilema que Pasolini tem diante de si: como representar uma tal coisa, um coro de deusas, as Erínias - as Fúrias - com a sua natureza aterradora? Como conceber a sua aparição, o seu "canto ancestral de terror e remorso"?* "As Fúrias" - diz o argumento, lido pela voz do realizador - sáo "as deusas do momento animal do homem", o signo abissal de uma irracionalidade selvática, e por isso "irrepresentáveis sob a aparência humana". Serão assim figuradas pelas "formas monstruosas" que pode assumir a natureza na África, pelos seus "silêncios profundos e assustadores", no estado extremo da maior crueldade, da solidão e do abandono: a câmara é
* (ÉSQUILO, Agamémnon, vv. 1184-1198, in: Oresteia. Agamémnon - Coéforas - Eumênides, Tradução do grego e notas de M.O. Pulquério. Lisboa: Ed. 70, 1998: 74.)

*(ÉSQUILO. Eumênides, vv. 299-306, op. cit.: 199-200.

* (Ibidem, vv. 309-320, op. cit.: 200.)

* (lbidem, vv. 329-331, op. cit., p. 200.)

* (Ibidem: 1189.) 
* (PASOLINI, Pier Paolo. Per il cinema I, op. cit.: 1183.)

* (Ibidem: 1195.)

*(Ibidem: 1185.)

* (PASOLINI, Pier Paolo. Pasolini on Pasolini. Interviews with Oswald Stack. Londres: Thames and Hudson; British Film Institute, 1969: 126.) dirigida para um grupo de árvores na floresta africana, e em seguida para uma "leoa ferida", que "poderia também ela ser uma Fúria”.*

Mais adiante ainda, ele retornará àquele que é para si o ponto de articulação decisivo da Oresteia, como foi já notado: o instante em que as Erínias, as deusas aterradoras da morte e da vingança, são transfiguradas, por efeito de uma estranha metamorfose, nas Eumênides. Ele vê nesta passagem uma síntese utópica, um ideal de conciliação pelo qual uma cultura arcaica irracional é preservada e mantida viva dentro das leis do mundo racional. Em conformidade com isso, continua procurando imagens que possam representar - "poética e metaforicamente"* - essa transformação, e voltará ainda a pressentir nas danças e cerimônias rituais das tribos africanas os sinais de uma tradição mágica, ou de um espírito antigo ainda não inteiramente perdido.

Mais uma vez, e num alinhamento perfeito com a eliminação da ideia convencional da "classicidade grega",* tudo aponta para uma identificação imanente: o coro aparece instantaneamente como o povo - em muitos sentidos à maneira de um reflexo, como acontecia no filme Édipo Rei, em que os cantos populares eram "de certo modo o substituto daquilo que era o coro na tragédia grega”, assim como a "função embrionária" do coro era então prontamente diferida ou transferida para o "canto incessante, contínuo e distante do povo", com o intuito de evitar a interrupção da ação em cada ocorrência dos versos do coro.* Nas Notas para uma Oresteia africana, porém, essa afinidade entre o coro e o povo deixa de ser simplesmente nominal ou substitutiva, para se ver potenciada até ao ponto da sua própria exaustão.

\section{"Terceiro Mundo" e Pré-História}

Perto do fim do filme, ouve-se ao longe uma canção revolucionária russa, como se os fundamentos ideológicos e o sentido de apropriaçáo que estão aqui em jogo se vissem retorcidos numa miragem que apela remotamente para a revolta e insurreição do povo africano. Mas não há verdadeiramente um culminar para o filme de Pasolini. A conclusão está "suspensa", não há lugar para uma resoluçâo linear, derradeira, nem para uma qualquer retórica da continuidade - medita ele no seu epílogo. Teve início a transformação da África, foi introduzida a figura formal da democracia e da liberdade: tudo é deixado nas mãos do povo, tudo depende 
da sua ânsia, da sua avidez pelo futuro. A voz-off retoma o lema de abertura, volta a exprimir confiança na conciliação e na síntese cultural: "As antigas divindades primordiais coexistem com o novo mundo da razão e da liberdade".* Mas o que fazer desta frase, que é também ela um verdadeiro refrão, preso à sua cadência indistinta, $\mathrm{e}$ cuja entoação aparentemente assertiva soa tão esbatida e indecisa?

A visão da África de Pasolini, vibrante ao toque da imagem obscurecida do mundo campestre ou do subproletariado que atravessam e impregnam desde muito cedo o seu cinema, emerge de um sentido profundo e doloroso da perda do instintivo, do puro e do pré-simbólico, do pré-histórico, para retomar os seus termos - e, por consequência, tende assim a exorcizar a nostalgia pela sua sobrevivência no mundo dito moderno.

Muito claramente, o arquétipo do Terceiro Mundo como único lugar de esperança que resta para a coexistência do arcaico (ou antigo) com o moderno, do mito com a autodeterminação, mostrou ser chão fértil para a paixão da contradição que animava a consciência artística e cívica de Pasolini, nos limites e para lá dos limites da sua própria apreensão individual do marxismo, repleta de hesitaçôes, retrocessos e novas irrupçóes de ânimo. A sua glorificação onírica do Outro, a sua tentação de entrever uma beleza, uma sacralidade originária nas condições da maior miserabilidade da vida, a sua tendência para confundir pequenez e grandeza, pobreza e integridade, humildade e degradação, possuíam a intensidade passiva própria de uma comoção estética. A atração pelo Terceiro Mundo foi em primeiro lugar uma afecção que se deu na iminência da afeição, e essa se cumpriu numa inclinação amorosa ou religiosa fechada em si mesma, no recolhimento da plena adesão ao seu objeto. Era pois uma "reação sentimental, mais do que ideológica", mas cedo "o afeto se tornou pouco a pouco ideologia", movido, e na verdade sacudido, pela "terrível nostalgia"* - da natureza, da justiça, da revolução, do irracional, do sacro - de que era feito. Está tudo prenunciado, e comprimido, numa passagem de As cinzas de Gramsci, na qual se encena o discurso de defesa da autocontradiçẫo e da autorrepresentação daquele que em face da sua honestidade não tem outra escolha senão trair-se a si mesmo: a sedução pelo exterior e pelo anterior acontece "no calor/ dos instintos, da estética paixão", e será "a força originária/ do homem, que se perdeu no ato,/ a dar-lhe a embriaguez da nostalgia,/ uma luz poética [...]”. O tom dilacerante evidencia a transparência da
* (PASOLINI, Pier Paolo. Per il cinema l, op. cit.: 11951196.)

* PASOLINI, Pier Paolo. Saggi sulla politica e sulla società, op. cit.: $1445,1417$. 
* (PASOLINI, Pier Paolo. "Le ceneri di Gramsci, IV". In:__. Tutte le poesie I, op. cit.: 820.)

* (PASOLINI, Pier Paolo. Per il cinema l, op. cit.: 1182.$)$

* (PASOLINI, Pier Paolo. “La vita quotidiana dell'Africa nuova (1968-1969)". In: DE PALMA, Mariana. Pasolini. Il documentario di poesia. Alessandria: Ed. Falsopiano, 2009: 185.) dedução: desde o início, tudo ocorre "no pensamento, numa sombra de ação".*

De forma quase pungente, o arquétipo - o Terceiro Mundo que deixa de ser dito ou escrito entre aspas - significa, pois, na prática e a longo termo, uma vontade de realidade que não pode senão coincidir com uma densa ideação, ou efabulação, para usar um termo caro ao seu autor, isto é, uma primeira - mas não última - tentativa de pôr em questáo o conceito de realismo, que Pasolini não se cansou de perseguir até ao fim da sua vida, e no fim do qual está novamente - a realidade. ${ }^{7}$ Já não se trata de discutir a densidade estilística dessa palavra, seja ela qual for, mas o seu peso próprio, a sua legitimidade histórica e meta-histórica, a decisão sobre a sua veracidade ou a sua falsificação.

Nas Notas para uma Oresteia africana, durante o seu diálogo com os estudantes africanos, Pasolini contesta com veemência os confins geográficos dos estados africanos, traçados ainda pelos poderes colonialistas e segundo os "padróes europeus", que dão a ver uma "realidade falsa".* A tentativa de fazer justiça à realidade - a "verdadeira" - se encontra, por exemplo, no plano para um documentário, nunca realizado, sobre a dilema em que se encontrava a África daqueles anos, colocada perante a escolha entre "socialismo e neocapitalismo".* Nos estudos de campo que resultaram das suas muitas viagens, Pasolini voltou a pôr em causa os limites cartográficos e territoriais em que tinham sido assimilados os diferentes povos africanos. No entanto, esse reconhecimento da infinidade de diferenças que separavam entre si as inúmeras tribos e comunidades da África, e que contrariavam a sua aparente integração sob o princípio unificador - mas sempre artificial e abstrato - do EstadoNação imposto pelo "neocolonialismo", acabaria por conduzi-lo a um pessimismo histórico latente. Com a exceção de algumas populaçôes que preservavam ainda uma vontade de autonomia e resistiam ao processo da industrializaçáo, o Terceiro Mundo parecia ter abraçado de vez o neocapitalismo, que se tornou assim global e irreversível. $\mathrm{O}$ empirismo antropológico de inspiração comunista ou socialista resultava assim num diagnóstico amargo: o contato automático e imediato do "homem pré-histórico" com o "mundo moderno" produzira naquele uma "catástrofe espiritual”, um vazio

${ }^{7}$ Cf. VIANO, Maurizio. A certain realism. Making Use of Pasolini's Film Theory and Practice. Berkeley/Los Angeles/Londres: University of California Press, 1993: 47-67. 
psicológico que o deixou numa "espécie de atordoamento, de estupefação ou de torpor", em que mesmo o estado da maior exaltação acabava por se confundir com a dormência e a letargia. A percepção desse conflito, próprio da transição vertiginosa, brutal do "sono pré-histórico" ao "sono neocapitalista", da sociedade tribal arcaica à civilização burguesa moderna, numa palavra, o reconhecimento da "crise da passagem de uma história a outra"* deixa já adivinhar em Pasolini uma oscilação, que ressurge sob várias formas - e com outras reviravoltas - em textos fulcrais da sua obra, como o guiáo $\mathrm{Il}$ padre selvaggio (1962) e o drama Pilade (1967), este último essencialmente uma variação sobre a Oresteia.

Confrontada com a expropriação do mítico e do sacro pela manifestação invasiva e inevitável da história ocidental e da modernidade, a imaginação revolucionária de um futuro pré-histórico vindo do Terceiro Mundo ressentiu-se do próprio rasto de frustração que deixava atrás de si. Com o alastrar do neocapitalismo por todas as classes e todos os espaços, não era já possível a Pasolini ignorar a colisão da sua alegoria com o fim a que ela aspirava, e ele viu desmantelar-se assim a sua própria distorção da realidade africana numa segunda distorção, agora concreta e imparável, observada in situ: a capitulação do mundo arcaico da tradição - os antigos "territórios coloniais" no processo da sua libertação e independência - perante a hegemonia total do mundo pós-industrial, do poder da burguesia e da "cultura de massa". A invocação esperançosa da imanência de uma realidade exterior e anterior ao mundo presente entrou em colapso diante dos seus olhos: o Outro tornou-se o Mesmo, o horizonte transformou-se numa massa uniforme e invariável; a diferença, o periférico, o marginal, o lugar para lá daquele em que nos encontramos, o "algures" deixou de existir - e o momento do desalento e da resignação acabou por chegar, não progressivamente, mas por saltos e interrupçóes constantes.

\section{O coro dissonante}

Também nas Notas para uma Oresteia africana, geralmente consideradas como o resíduo otimista da coexistência e "convivência" entre dois mundos, o narrador parece interiorizar lentamente as ambivalências, as falhas e os equívocos do seu ideal, à medida que se vai tornando cada vez mais abstrato e circunspecto. Antes de formular o seu epílogo, Pasolini se detém numa pequena aldeia da Tanzâ-
* (PASOLINI, Pier Paolo. "Nell'Africa nera resta un vuoto fra i millenni (1970)". In:___ Saggi sulla politica e sulla società, op. cit.: 209-210.) 
* (PASOLINI, Pier Paolo. Per il cinema I, op. cit.: 1194.)

* (Ibidem.)

* (PASOlINI, Pier Paolo. "Sopraluoghi in Palestina (1964)". In:__. Peril cinema l, op. cit.: 656.)

* (PASOLINI, Pier Paolo. Per il cinema I, op. cit.: 1195 .) nia: a sua câmara é fixada na dança que acompanha os cerimoniais e as festividades daquela localidade, "uma dança dos tempos antigos”, diz ele, e acrescenta: “antigos é um modo de dizer”, já que os habitantes da tribo se limitam agora a repetir, por simples diversão e alegria, os gestos e os movimentos de um rito que teve outrora "significados precisos, religiosos, talvez cosmogônicos", esvaziando -os assim de algum modo do seu "antigo significado sacro". Após uma pequena pausa, a voz-off conclui, em contraponto: "Eis uma metáfora daquela que poderia ser a transformação das Fúrias em Eumênides".* Segue-se uma citação do episódio central da tragédia de Ésquilo: as Fúrias (Erínias) são persuadidas pela deusa Atena a "coexistirem com ela, a deusa da razão, essas deusas da irracionalidade, no novo mundo, no novo mundo independente democrático e livre”. De regresso ao filme, o cenário muda, a situação mantémse inalterada: numa cidade de Tanganika, as posturas, os gestos, a mímica, os "acenos de dança” da população são lidos como sinais de um "mundo mágico" do passado; de novo é desenhada a analogia, no tempo presente desejado: esta situação "pode perfeitamente representar, poeticamente e metaforicamente, a transformação das Fúrias em Eumênides”.*

Esta transição diz tudo - ou quase - sobre a relação de Pasolini com o Terceiro Mundo. Da mesma forma que nos Sopralluoghi in Palestina (1964) exalava do seu discurso alguma decepção, à vista de "uma paisagem, digamos assim, contaminada pela modernidade",* ele se mostra desapontado por não encontrar aqui, nos festejos e nas danças dos africanos, o "antigo espírito autóctone"* que tinha previsto para elas e que quis pressentir nelas, senão como um vestígio, uma dissipação em curso. Os próprios “atores”, as próprias figuras, no entanto, não parecem reconhecer-se na suposta deterioração da sua identidade, e é visível a sua distância em relação à aura de vitimização que lhes é aduzida, imposta unicamente pelo comentário do diretor. Aos olhos deste último, os movimentos dos camponeses parecem já demasiado impuros, tocados ou profanados pela consciência moderna, demasiado submissos à disseminação dos costumes do Ocidente secular degenerado.

Quando a revelação da marginalidade potencialmente revolucionária do Terceiro Mundo, e da África como substrato irracional de um passado imemorial que resiste à história (neocapitalista), se viram abaladas ou traídas pelo próprio objeto da sua afeição, como acontece nos exemplos das danças tribais citados acima, a crença 
de Pasolini vacilou, e a ilusão foi acometida pela inaptidão que trazia dentro de si. O grau de pureza ou de autenticidade da realidade imediata é sempre insuficiente e não saberia nunca corresponder - ou simplesmente responder - ao conceito exasperado e confiante da "verdadeira" realidade, por princípio ilimitada e indefinível.

Dadas estas circunstâncias, não parece haver dificuldade alguma em diagnosticar em Pasolini o seu "encontro falhado com o Terceiro Mundo", isto é, em denunciar o seu projeto e a sua "posição ideológica" de um "Outro (neo-)exótico" como "um sonho impossível, e a promessa de transgressáo que oferece nada mais (mas nada menos) do que uma questáo de retórica".* Mas, conhecendo a sinceridade visceral da auto-reflexão de Pasolini, há algo de claramente inútil em enumerar os seus vícios dialéticos para desmascarar aquilo que seria a "categoria totalizante" e o "imperativo monolítico" da sua ideia do pré-histórico, ${ }^{*}$ e apresentar assim o modo da sua aproximação à alteridade como a prova fatal do seu "declínio ideológico" e do "falhanço radical" do seu "tiers-mondisme" como trajetória existencial, literária e política. * Pretender, para além disso, que nesse "fim da linha" - no qual rondaria apenas uma "abjuração amargurada" da crença precedente, ou a última tentativa abortada de uma recuperação, recriação ou re-visão do passado - se mostra unicamente uma insuficiência, uma indefinição, uma fuga elíptica no indefinido, ou uma "ausência de obras", ${ }^{* 8}$ equivale já a confundir todos os planos, das causas às consequências.

Pasolini foi o primeiro a identificar as contradiçóes que assolavam o seu pensamento, e é justo dizer que no seu "resvalar entre um objeto fantasmático e um objeto real”* se repercute o desacerto, o paradoxo que liga a sua firmeza teórica à dor da incerteza que o habitava. O efeito de desilusão da sua autoprojeção no mundo exterior foi também um efeito do olhar: o desmoronamento do real idealizado coincide com o instante em que o fardo inevitável do presente apagou o desejo do passado como possibilidade de futuro, pondo à vista a sua irrealidade.

\footnotetext{
${ }^{8}$ Bongie reserva no seu texto uma única referência fortuita ao filme-poema "sobre o Terceiro Mundo" e às Notas para uma Oresteia africana (op. cit.: 220-221). Para uma leitura mais sóbria e exaustiva do tema da relaçáo com o "Terceiro Mundo”, cf.: TRENTO, Giovanna. Pasolini e l'Africa. L'Africa di Pasolini. Milano Udine: Mimesis Edizioni, 2010. Caminatti, Luca. Orientalismo eretico: Pier Paolo Pasolini e il cinema del Terzo Mondo, Milano: Mondadori, 2007.
}

* (BONGIE, Chris. "A Postscript to Transgression - The Exotic Legacy of Pier Paolo Pasolini". In: Exotic Memories. Literature, Colonialism, and the Fin de Siècle. Stanford, California: SUP, 1991: 191.)

*(Ibidem: 206-207.)

* (Ibidem: 227, 203.)

*(Ibidem: 224, 218, 191.)

* (Ibidem: 215.) 
No entanto, o que há de peculiar na intencionalidade do seu gesto é que ela não obedece a qualquer sentido de linearidade. A sua única lei não é periódica, mas cíclica, no sentido literal da plena circularidade, e avança apenas pela repetiçáo incessante do mesmo: ao desencanto, nunca dado como definitivo, é sempre contraposta uma nova insistência, à descrença responde uma nova confiança, e do seu fundamento precário reemerge descontinuamente uma obstinaçáo árdua e sem nome.

Essa lei, ou essa variação, assume contornos muito particulares nas Notas para uma Oresteia africana. Por um lado, porque o argumento, o ponto de apoio da sua insistência depende de uma única obra de arte, a Oresteia, um texto autônomo que, de alguma forma, representa toda a poesia trágica grega de forma monumental e quase avassaladora, um texto que se trata náo de restituir segundo um modelo pré-definido, mas de submeter à vontade, ao mesmo tempo literal e irreal, de transposição de um mundo num outro mundo, e que por isso não está em dívida para com uma lógica de ascensão e queda. Por outro lado, porque essa obstinação constitui o núcleo do próprio ato poético, o qual só é capaz de conceber as condições da sua sobrevivência - da sua condição potencial estando ou permanecendo ligado a si mesmo na obsessão (impossível) do que lhe é exterior.

É isso que transparece na noção do coro antigo ressuscitado na África moderna. À partida, no primeiro olhar, ele é o sombreado da pura expressividade poética - quer sob a forma da simplicidade e do despojamento, como nos retratos aleatórios da vida quotidiana dos africanos; quer na vertigem da improvisação, como na interpretaçâo gutural da música jazz; quer ainda sob os auspícios da graciosidade e da nobreza, como nas danças e cerimônias rituais do povo captadas com um ar de admiração e reverência. Cada um desses exemplos procura encarnar o coro de Ésquilo engendrando-o dramaticamente, induzindo-o literalmente no elemento corpóreo da película - e no entanto, náo obstante o seu lado insinuante, o seu efeito de sedução, todos fracassam no seu propósito. À chegada, no reflexo do olhar, o coro revela ser inexistente, algo de curvado e perdido na sua imediatez irrealizável, aquilo para o qual nenhum correlato parece empiricamente convincente: um vulto, enclausurado no ínfimo assombroso, uivante ou longínquo, da sua palavra. Desse ponto de vista, há no seu canto - e muito em especial no coro das Erínias - algo de inaudível, de inexprimível, que resulta da sua elo- 
cução lúgubre e funesta, desarticulada, mas que não é ainda possível reduzir ao simples mutismo da língua gerada pela assombração, intangível ou sem-corpo, do indomável e do inumano. ${ }^{9} \mathrm{O}$ seu tom é antes o de uma introversão: monocórdico, absorto em si mesmo e distante de toda a elevação ou sublimidade, responde apenas a si mesmo, e quase se torna alheio ao objeto do seu discurso, ao contexto e ao espaço que o circundam. À medida que o "realístico" e o "verdadeiro" vão sendo revirados para uma superfície interna, a sua consonância se desvanece, e espelha assim a clarividência encurralada em si mesma em que cai qualquer idealização extrema da realidade, quando se vê obrigada a voltar a si. Toda a recomposição, toda a figuração do canto e da dança, entra doravante no seu vácuo - que é também o espaço da sua fecundidade mais própria.

\section{Uma fábula do realismo}

Em muitos sentidos, essa percepção imaginária, historicamente irreal e profundamente individual do coro (e do mundo) antigo serve de preâmbulo tanto à gênese da analogia entre a esfera do mito grego e a emancipação da história africana na segunda metade do século XX, quanto à sua execução - de algum modo intencionalmente - falhada. Uma tal relação teria sempre de se contar entre as analogias "arbitrárias e poéticas, e em parte até irracionais", como o reconheceu Pasolini* - inerentes como eram ao seu auto-proclamado "amor pela realidade", que tinha de acabar minado, corroído e deposto pela própria realidade. Sempre que a dialética da proximidade e da distância mostra o seu lado opaco, o histórico se dissolve a perder de vista no mítico, e repete assim todo o seu percurso: do lamento por uma realidade perdida, e por isso desejada (o objeto construído), passando pelo sacrifício a que se entrega a realidade representada (o objeto filmado), até à sua decomposição involuntária - que decide não da sua absolvição, nem da sua abjuraçáo total, mas do seu recomeço.

Do processo em si nasce não uma didascália aposta às apariçôes do povo, à imagem do que Pasolini pensara em fazer com os

\footnotetext{
${ }^{9}$ Cf. BALDARELLI, B. "Den Erinnyen eine Stimme verleihen - Pasolini, die Orestie und die Sprache des Mythos.” In: JUNKE, C.; SCHWARZE, M. (org.): Unausweichlichkeit des Mythos. Mythopoiesis in der europäischen Romania nach 1945: Munique: M. Meidenbauer, 2007: 72-73, 76-77 - onde se fala, a propósito do canto das Erínias entendido como "linguagem autêntica do mito", de "afasia” e de um grau-zero da língua.
} 
* (ROHDIE, S. "And Africa?" In: ___ The Passion of Pier Paolo Pasolini, Bloomington/Indianapolis: British Film Institute/ Indiana University Press, 1995: 107-108.)

* (PASOLINI, Pier Paolo. Pasolini on Pasolini, op. cit.: 38.)

* (PASOLINI, Pier Paolo. Saggi sulla politica e sulla società, op. cit.: 1391.)

* (GARDI, K. "The Crisis of Transition: Pier Paolo Pasolini's African Oresteia". In: Quaderni d'Italianistica, 17/1 (1996): 94.)

* (BONGIE, C. "A Postscript to Transgression - The Exotic Legacy of Pier Paolo Pasolini". In: Exotic Memories. Literature, Colonialism, and the Fin de Siècle, op. cit.: 207.) versos do coro da Oresteia, mas um outro tipo de aderência: a voz, sobreposta às imagens, está unida à sua extensão, mas encontra-se - nesse instante e para sempre - fora de campo. Seria também este o caso da justaposição dos ritos e danças populares africanas com a transfiguração das Erínias, da dúvida meditativa à confiança impulsiva que suscitam no seu próprio autor: quando a realidade física já não responde ao ideal sonhado pelo poeta, este se lança sobre ela, para a envolver de uma vez por todas no "mito de um mito", e assim entrar "ficcionalmente [...] no seu círculo como se este fosse real".*

Aqui jaz o vínculo quebrado e o arcaísmo áspero, despovoado da Oresteia "ambientada" em África, vista como a construção poética instável, movediça que é: um conjunto contraposto de palavras e imagens para uma fábula sonhada do realismo, expondo a imersão no mito (guardado no coração de um texto) através do próprio ato desdobrado de mitificação (de um continente inteiro), fixado apesar de tudo a si mesmo. Atrás de si ficam as "notas" para um filme: o desígnio da obra que ficou e ficará sempre "por fazer", de acordo com seus méritos e dos seus fracassos, passa a se resumir ao poder da evocação, algo de ténue e obscuro, que, contudo, permanece inabalável - por não ser mais do que um esboço, uma anotação que se antevê a si mesma como obra fragmentária.

A cada passo, toda a concepção original do cinema como linguagem metonímica, que torna possível à realidade exprimir-se "a si mesma por si mesma"* é ensombrada pela tentação do seu oposto, o metafórico e o simbólico. Por sua vez, a metáfora que luta com o seu desaparecimento não é mais do que a penumbra e a refração desse mito do mito, a pré-história da pré-história que ignora o seu próprio fim, e que se encontra na raiz do "cinema de poesia".

A natureza física do cinema é poética porque partilha a fisionomia da recordaçáo e do sonho: nele se exprime, sem mediação, "a própria realidade" em si mesma, a materialidade própria das coisas, no modo "pré-histórico, informe, não natural".* É próprio do sonho o seu fundo intocável, e do estado sonhador o desfazer-se no momento preciso em que revela a sua figura. Seria essa também a matéria que induz a tensão, o impasse em que são deixadas as várias "ficçóes" que compóem as Notas para uma Oresteia africana, não por poderem ser enaltecidas devido ao seu "valor operativo" e à "percepção holística"* que geram à sua volta, ou rebaixadas à inocuidade de uma "construção essencialmente retórica",* mas quando são assumidas na sua escassez 
e na sua profusão que compreende a forma vacilante e, contudo, inexpugnável do seu lastro.

Porquanto alude apenas a um gesto que tem ainda de ser cumprido, e que se revela presente por momentos apenas no vislumbre, na luz trêmula da sua promessa, a projeção arquipolítica manifesta de Ésquilo e a aparição do coro das Erínias - no qual está subsumido o corpo sonhado de uma concordância ou de uma ordem simétrica do mundo arcaico com a racionalidade e o índice evolutivo da história - não têm de ser julgadas pela sua incoerência face ao processo efetivo da história, na sua anterioridade ou na sua posteridade. Em vez disso, essas "Notas" configuram o prelúdio a um projeto cujo mote principal e cuja realização são deixados a oscilar na própria extremidade, no próprio precipício da sua dissolução, resguardando simultaneamente os meios e a fonte da sua regeneração. A “Oresteia africana” constitui um postulado que, para poder existir, teve e tem de ser privado da necessidade do seu desfecho. Permanecerá sempre, para regressar aos termos triviais e frontais de Pasolini, uma iniciação poética "arbitrária” e uma criação lírico-política “irracional” do espírito, destinada a não se cumprir, exceto no desenlace sempre adiado da incompletude que lhe é própria - em que a possibilidade da própria coisa vive inexoravelmente da sua impossibilidade.

Bruno C. Duarte tem doutorado em Filosofia pela Universidade Marc Bloch - Strasbourg, onde estudou com Philippe Lacoue-Labarthe. Seu trabalho incide sobretudo sobre a filosofia do Idealismo Alemão, Teoria da tragédia e Poética dos séculos XVIII e XIX, em particular sobre autores como F. Hölderlin, H. von Kleist, F.W.J. Schelling ou F. Schlegel, entre outros. É atualmente membro do Instituto de Filosofia da Linguagem da Faculdade de Ciências Sociais e Humanas - Universidade Nova de Lisboa. E-mail: <hh1846@gmail.com>. 